\title{
Open Educational Resource Textbook Impact on Students in an Introductory Nutrition Course
}

\author{
Marie K. Fialkowski, PhD, RDN, LD ${ }^{1}$; Allison Calabrese, BA ${ }^{1}$; Beth Tilinghast, MEd $^{2}$; \\ C. Alan Titchenal, PhD, CNS ${ }^{1}$; William Meinke, $\mathrm{MEd}^{3}$; Jinan C. Banna, PhD, RDN ${ }^{1}$; \\ Jennifer Draper, MA, RDN, LD ${ }^{1}$
}

\begin{abstract}
Objective: To determine if student outcomes, usage, perceptions, and engagement differ between introductory nutrition courses that used an open educational resource (OER) textbook compared with a traditional textbook.

Design: Cross-sectional.

Setting: College introductory nutrition course.

Participants: Students enrolled in introductory nutrition courses that used a traditional textbook or an OER textbook.

Intervention: Implementation of an OER textbook in all introductory nutrition courses during 1 semester.

Main Outcome Measure(s): Usage, perceptions, and engagement with the textbook were evaluated by an online survey. Student outcome data (eg, grades) were collected from the learning management system at the end of the semester.

Analysis: Differences in student outcomes, usage, perceptions, and engagement were determined by t tests. Open-ended responses on textbook likes and dislikes were evaluated by thematic analysis.

Results: The number of students who completed the introductory nutrition course with a traditional textbook $(n=346)$ was higher than those who completed the course with an OER textbook $(n=311)$. There was no difference in student outcomes between textbooks. $P$ values for student usage ranged from $<.001$ to $.001,<.001$ for engagement, and <.001 to .001 for perception with the OER textbook, with significantly better $P$ values for outcomes than those with the traditional textbook. The $\$ 0$ cost and place-based nature were noted as positive attributes of the OER textbook, whereas students appreciated the format and visual appeal of the traditional textbook.

Conclusions and Implications: Academic performance in introductory nutrition was not affected by an OER textbook. An OER textbook for introductory nutrition may be an appropriate solution for institutions seeking to reduce student costs.
\end{abstract}

Key Words: nutrition science, education, open education resource (J Nutr Educ Behav. 2020; 52:359-368.)

Accepted August 14, 2019. Published online September 13, 2019.

\section{INTRODUCTION}

American college students must spend more than $\$ 1,100$ per year to cover the costs for textbooks and supplies ${ }^{1}$ because the price of college textbooks has increased by $87.5 \%$ from 2006 to $2016 .^{2}$ A 2013 survey by the Student Public Interest Research Group found that $65 \%$ of students reported not buying a textbook because of price, despite $94 \%$ believing they would do

\footnotetext{
${ }^{1}$ Department of Human Nutrition, Food, and Animal Sciences, University of Hawai'i at Mānoa, Honolulu, HI

${ }^{2}$ Learning Design and Technology, University of Hawai'i at Mānoa, Honolulu, HI

${ }^{3}$ Outreach College, University of Hawai'i at Mānoa, Honolulu, HI

Conflict of Interest Disclosure: The authors have not stated any conflicts of interest.

Address for correspondence: Marie Kainoa Fialkowski, PhD, RDN LD, University of Hawai'i at Mānoa, 1955 East West Road, Ag Sciences 314J, Honolulu, HI 96822; E-mail:

mariekf@hawaii.edu

(C) 2019 Society for Nutrition Education and Behavior. Published by Elsevier Inc. All rights reserved.

https://doi.org/10.1016/j.jneb.2019.08.006
}

worse in the course without the textbook(s). The survey also found that $48 \%$ of students admitted that the cost of textbooks affected the number of courses they enrolled in each semester. In addition, $82 \%$ of students stated they would do significantly better if textbooks were available for free online. ${ }^{3}$

In alignment with efforts to reduce costs for students and increase access, openly licensed textbooks, or otherwise referred to as open educational resource (OER) textbooks, have increased in popularity. Open educational resources are educational materials that are either (1) licensed under an open copyright license (eg, Creative Commons) or (2) in the public 
domain and therefore freely accessible and able to be revised, remixed, reused, and redistributed by others. ${ }^{4}$ Open educational resource textbooks give instructors the freedom to control content provided to their students. Preliminary research has found that students prefer using an OER textbook instead of a publisher's textbook $^{5}$ and are more likely to access the OER textbook compared with the publisher's textbook. ${ }^{6}$ In addition, there is evidence to suggest improved student performance in courses with an OER textbook. ${ }^{6,7}$

Introductory nutrition is a foundational course for undergraduate nutrition programs. For many institutions, the introductory nutrition course may also satisfy university general education requirements. ${ }^{8}$ Introductory nutrition provides the student learner with foundational knowledge in nutrition including the basic review of nutrients, their role in human health, and nutrient needs throughout the life span. Introductory nutrition is 1 of the most common nutrition courses offered online. ${ }^{9}$

The COUP framework was developed by the Open Education Group to provide a consistent approach to studying the impact of OERs (like open textbooks) and open pedagogy in secondary and postsecondary education. ${ }^{10}$ The COUP framework focuses on Cost, Outcomes, Usage, and Perceptions of OER. In COUP, usage can focus on both how a student actually uses the resource-time spent and percentage of material used-and on how the material is used, using the legal permission of the open licenses attached to the OER.

There is a paucity of OER research in nutrition. Only 1 study has been conducted in nutrition focusing primarily on student preference for an OER textbook over a traditional textbook. ${ }^{5}$ Further research is needed to examine the impact that OER textbook adoption has on student outcomes, usage, perceptions, and engagement. To the authors' knowledge, no other study at this time has included the concept of engagement as a factor affecting a student's experience with OER, making this study unique. Previous research has demonstrated the importance of engagement in online nutrition courses. ${ }^{11}$ In addition, none of the studies conducted so far have examined OER textbook adoption in Native Hawaiian, Pacific Islander, and Asian student populations. This study will contribute new knowledge on OER textbooks for nutrition by addressing the following research questions: (1) Do students enrolled in a nutrition course who use an OER textbook perform better in terms of grades in the course than those who use traditional textbook (Outcome)?; (2) Do students enrolled in a nutrition course who use an OER textbook rate the course textbook higher than those who use a traditional textbook (Perception)?; (3) Do students in a nutrition course who use an OER textbook engage more in the course than those who use a traditional textbook (Engagement)?; and (4) Do students enrolled in a nutrition course who use an OER textbook use the textbook more fully than those who use a traditional textbook (Usage)?

\section{METHODS}

\section{Study Design}

This study applied selected components of the COUP framework and also incorporated an extension of the COUP framework, engagement, to determine if there is a difference in the level of engagement with the material. Engagement includes time spent using the resource and the proportion of the material read. This construct examines the domains of interest, challenge to student thinking, understanding, and appropriateness of the material that parallels the learning objectives for the course. $^{12}$

Given the opportunity to customize OER textbooks, the authors of the nutrition textbook purposely chose to create a place-based ${ }^{13}$ textbook to align with a student population that is predominantly in-state residents rather than a textbook developed for a universal audience. The authors speculated that this may improve engagement with the textbook over a traditional publisher textbook that is produced on the contiguous US. The authors of the OER textbook included 2 faculty members and 2 graduate assistants in the Department of Human Nutrition, Food and Animal Sciences at the University of Hawai'i at Mānoa and the university's OER technologist. Over the course of 1.5 years, the OER textbook was developed to reflect the diverse dietary patterns of people in Hawai'i and the greater Pacific.

\section{Participants and Recruitment}

Participants in this study included students who enrolled in introductory nutrition at the University of Hawai' $i$ at Mānoa during the 2017-2018 academic year (fall and spring semester). Three sections of introductory nutrition are offered each semester. Two of the sections are offered face-to-face, whereas the third is offered online. Mode of delivery (eg, face-to-face, online) by the 3 instructors was consistent between the 2 semesters (eg, the same instructor taught online in the fall and the spring). During the fall semester, all sections of the course were taught with a traditional textbook (traditional group), whereas in the spring semester, the traditional textbook was replaced with an OER textbook developed specifically for the institution (OER group). An exempt approval was received from the Institutional Review Board of the University of Hawai'i at Mānoa. All students consented before completing the online survey.

\section{Instruments and Measures}

A previously developed survey ${ }^{14}$ assessing usage and perceptions was adapted for this study (Supplementary Data). The survey was then reviewed by an expert in OER research and then pretested in a University of Hawai'i at Mānoa summer section of introductory nutrition before implementation. Minor grammatical changes were made to the survey following the results of the pretest. The survey was administered online using Qualtrics Survey Software (Qualtrics, Provo, UT, 2017). Final grades for every student were provided by the instructors in a deidentified format from the course learning management system set to compare the traditional textbook 
group's grades with the OER textbook group's grades.

\section{Data Analysis}

Quiz and exam scores were converted into numeric grade point average equivalents (eg, $\mathrm{A}=4)$. To establish the extent to which the groups are equivalent in their initial knowledge of the content, quiz performance at the beginning of the course was compared using $\mathrm{t}$ tests. In addition, to determine impact on final course performance, $t$ tests were used to determine if final examination grades among students in the OER textbook group differed significantly from final examination grades among students in the traditional textbook group. The percentage of students who dropped, withdrew, and received a final grade of $\mathrm{C}$ or better was calculated. The course throughput rate (CTR), which combines the effect of drop rates, withdraw rates, and final grades, was calculated as follows: ([total students registered on day 1$] \times[1-$ drop rate $] \times$ $[1$ - withdrawal rate] $\times$ [percentage passing with a C or better]) / (total students registered on day 1). ${ }^{15}$ The CTR shows the percentage of students present on the first day of class who completed the course with a final grade of $\mathrm{C}$ or better, providing a gauge on the overall success rate from registration to final grade. A t test was used to determine if the CTR of OER group differs significantly from the CTR of sections in the traditional group. Furthermore, $t$ tests were also used to compare if survey responses related to usage, perception, and engagement of OER with that of traditional resources were different between the 2 groups. All quantitative analyses were conducted in IBM SPSS Statistics version 25.0, SPSS Inc, Chicago, IL, 2017.

To provide additional insight on survey results, open-ended responses to the survey questions, "What are the features, if any, that you liked about the textbook for this class?" and "What are the features, if any, that you disliked about the textbook for this class?" were coded by hand using thematic analysis by 2 different reviewers. ${ }^{16}$ Two independent reviewers coded all the responses achieving a mean Cohen kappa coefficient of 0.91 indicating excellent agreement. ${ }^{17}$ After each of the 2 independent reviewers coded the responses, the 2 reviewers met to discuss and agree upon the final coding. A third, independent reviewer, then coded the open-ended responses by hand using the agreed upon final codes to confirm with the first 2 reviewers. Responses were compared across groups.

\section{RESULTS}

Approximately $11 \%$ fewer students were enrolled in the introductory course that used the OER textbook $(\mathrm{n}=311)$ compared with those who used the traditional textbook $(n=346)$. However, as shown in Table 1, the characteristics of both groups were similar, with approximately $60 \%$ of students being female, approximately $50 \%$ identifying as Asian, more than $90 \%$ being between the ages of 18 and 25 years, more than $50 \%$ being classified as a freshman or sophomore, and approximately $70 \%$ having a credit load of 13 or more. Approximately one third of both groups preferred not to share their overall household income. Performance in the course, as assessed by the initial course quiz, final examination, and final course grade, was also not statistically different between the 2 groups. As shown in Table 2, there was also no significant difference in the number of students who dropped, withdrew, or received a grade of $\mathrm{C}$ or better. The CTR was also not significantly different between the 2 groups.

Students rated their usage, engagement, and perception with the OER textbook significantly better than with the traditional textbook (Table 3). More than half of the students in both groups $(64 \%[\mathrm{n}=223]$ and $59 \%[n=205]$, respectively) provided comments on what they liked about both textbooks related to its structure, access, and interpretation of information (Table 4). As expected, a number of students liked the $\$ 0$ cost, convenience, and ease of navigation of the OER textbook. However, the traditional textbook's format and organization, as well as visuals, were appealing to students. Although students in both semesters commented on the applicability of the textbook, the students who used the OER textbook specifically commented on liking its place-based nature as the OER textbook reflected the unique history, culture, and food of the Pacific. Approximately half of the students in both groups $(55 \%[\mathrm{n}=190]$ and $49 \%[n=153]$, respectively) provided responses with regard to what they did not like, indicating that the OER textbook needed further improvement in the format and organization, as well as the navigation (Table 5). A number of students responded that there was nothing they disliked about the textbooks.

\section{DISCUSSION}

This study found that students who used an OER textbook performed similarly to those who used a traditional textbook. This is similar to another study examining the impact on student performance in a chemistry course, which found that there were no significant differences between students who used an OER textbook compared with those who did not. ${ }^{18}$ This also corroborates a review of OER studies that found that students perform just as well as those who use a traditional textbook. ${ }^{19}$ The significant amount of cost savings to students, without sacrificing performance, is important to note. Based on the cost of a new textbook purchased at the University of Hawai'i at Mānoa bookstore, the use of an OER textbook would have saved over $\$ 39,000$ (\$127.50/student) in the fall 2017 semester.

This study did not find that the CTR was significantly improved with the replacement of a traditional textbook with an OER textbook. This is contrary to another study that found that CTR was significantly improved when a traditional textbook was replaced with an OER textbook. ${ }^{15}$ However, this study was conducted in a community college, across multiple degree programs, and did not account for potential student differences by the initial class quiz as was done in this study. It is important to note that initial course quiz scores did not differ between groups, demonstrating an equivalent group at the outset. Most OER studies do not account for initial differences in groups. ${ }^{19}$ 
Table 1. Characteristics and Grade Performance of Students Who Completed an Introductory Nutrition Course That Used a Traditional Textbook $(n=346)$ Compared With Students Who Used an OER Textbook $(n=311)$

\section{Characteristic}

Gender $^{b}$

Male

Female

Race/ethnicity ${ }^{c}$

White

Black or African American

American Indian or Alaska Native

Hispanic or Latino

Asian

Chinese

Filipino

Indian

Japanese

Korean

Vietnamese

Other

Native Hawaiian or Pacific Islander Micronesian

Chamorro

Native Hawaiian

Samoan

Tongan

$\mathrm{Age}^{\mathrm{d}}$

Other

$18-25$

26-30

$31-35$

$36-40$

41-50

51 and older

Year in school ${ }^{\mathrm{d}}$

Freshman

Sophomore

Junior

Senior

Graduate

Other

Household income ${ }^{c}$

Less than $\$ 24,999$

$\$ 25,000-\$ 34,000$

$\$ 35,000-\$ 49,000$

$\$ 50,000-\$ 74,000$

$\$ 75,000-\$ 99,000$

$\$ 100,000-\$ 149,000$

$\$ 150,000$ or more

Prefer not to say

Semester credit load ${ }^{\mathrm{e}}$

$1-3$

$4-6$

$7-9$

$10-12$

13 or more

Course performance

Quiz 1

Final examination

Course grade
Traditional Textbook, n (\%) ${ }^{a}$

OER Textbook, n (\%)

$$
\begin{gathered}
133(39) \\
207(61) \\
61(22) \\
10(4) \\
4(1) \\
24(9) \\
130(47) \\
22(8) \\
42(15) \\
2(1) \\
47(17) \\
11(4) \\
5(2) \\
1(1) \\
43(16) \\
4(1) \\
5(2) \\
27(10) \\
7(3) \\
0(0) \\
0(0)
\end{gathered}
$$

$257(94)$

9 (3)

$3(1)$

$1(1)$

2(1)

$1(1)$

$74(27)$

$79(29)$

$73(27)$

42 (15)

$1(1)$

$5(2)$

$41(15)$

$13(5)$

35 (13)

25 (9)

25 (9)

$38(14)$

20 (7)

75 (28)

5 (2)

$11(4)$

10 (4)

$59(22)$

188 (69)

$4.50(1.1)$

$74.60(17.3)$

$83.30(15.3)$
$114(37)$

$192(63)$

59 (22)

9 (3)

1 (1)

15 (6)

$146(54)$

30 (11)

50 (19)

1 (1)

$48(18)$

$10(4)$

2 (1)

$5(2)$

$38(14)$

3 (1)

3 (1)

25 (9)

$3(1)$

2 (1)

$2(1)$

244 (91)

$11(4)$

$3(1)$

7 (3)

$0(0)$

3 (1)

$97(36)$

75 (28)

38 (14)

47 (18)

$5(2)$

$6(2)$

$43(16)$

25 (9)

$18(7)$

26 (10)

17 (6)

23 (9)

22 (8)

$94(35)$

$3(1)$

9 (3)

8 (3)

57 (21)

191 (71)

Mean (SD)

$4.51(1.2)$

$73.32(18.6)$

$82.38(16.4)$

OER indicates open educational resource.

${ }^{\text {a }}$ Percentages may not add up to 100 because of rounding; ${ }^{b}$ Data were unavailable for 6 students in the traditional textbook semester and 5 students in the OER textbook semester; ' $T$ Total number of students completing this question was 272 in the traditional textbook semester and 268 in the OER textbook semester; ${ }^{d}$ Total number of students completing this question was 274

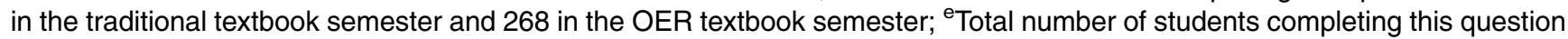
was 273 in the traditional textbook semester and 268 in the OER textbook semester; ${ }^{f}$ Quiz score ranged between 0 and 5 , whereas the final examination score and the final course grade ranged from 0 to 100 . 
Table 2. Drop, Withdrawal, Grades Better Than C, and CTR for Students Who Completed an Introductory Nutrition Course That Used a Traditional Textbook $(n=346)$ Compared With Students Who Used an OER Textbook $(n=311)$

\begin{tabular}{llcc} 
Outcome & \multicolumn{1}{c}{ Value } & $\begin{array}{c}\text { Traditional } \\
\text { Textbook }\end{array}$ & $\begin{array}{c}\text { OER } \\
\text { Textbook }\end{array}$ \\
Drop & $\mathrm{n}(\%)$ & $40(12)$ & $31(10)$ \\
& t score & 0.673 & \\
Withdrawal & $P$ value & .54 & $4(1)$ \\
& $\mathrm{n}(\%)$ & $6(2)$ & \\
Grade $\geq \mathrm{C}$ & t score & 0.40 & $285(92)$ \\
& P value & .71 show & \\
CTR & $\mathrm{n}(\%)$ & $289(84)$ & \\
& t score & 0.33 & \\
& Pvalue & .75 & \\
& Mean (SD) & $241(69)$ & \\
& t score & -0.20 & \\
& $P$ value & 0.85 & \\
\hline
\end{tabular}

CTR indicates course throughput rate; OER, open educational resource.
Students' usage, engagement, and perception of the OER textbook were better than those associated with the traditional textbook use. This is similar to a previous study examining student perceptions in multiple introductory nutrition course sections taught in a single semester as well as across semesters. ${ }^{5}$ These findings are also similar to other studies across various disciplines. ${ }^{20,21}$ The improved accessibility commented on by students was similar to another study examining the use of an OER with health psychology students. ${ }^{22}$

\section{Limitations}

This study was unable to report findings separately by mode of instruction (eg, online vs face-to-face) although the study did control for

Table 3. Student Responses to Survey Questions Related to Usage, Perception, and Engagement With the Traditional Textbook and the OER Textbook

\begin{tabular}{|c|c|c|c|c|c|}
\hline Category & Question & mean (SD) & mean (SD) & $t$ test & $P$ value \\
\hline \multirow[t]{3}{*}{ Usage $^{a}$} & $\begin{array}{l}\text { How often did you use the textbook for this } \\
\text { course? }\end{array}$ & $3.3(1.14)$ & $3.0(0.96)$ & 3.30 & .001 \\
\hline & $\begin{array}{l}\text { How did you actually use the textbook } \\
\text { during the course? }\end{array}$ & $3.1(1.06)$ & $2.5(0.96)$ & 6.67 & $<.001$ \\
\hline & $\begin{array}{l}\text { Approximately how much of the textbook } \\
\text { did you read over the length of the } \\
\text { course? }^{\text {d }}\end{array}$ & 3.7 (1.03) & $3.4(0.96)$ & 3.28 & .001 \\
\hline \multirow[t]{3}{*}{ Perception } & $\begin{array}{l}\text { Overall, the quality of the textbook for this } \\
\text { course was... }\end{array}$ & $3.0(1.43)$ & $2.5(1.31)$ & 4.05 & $<.001$ \\
\hline & $\begin{array}{l}\text { The textbook helped me to understand } \\
\text { concepts in this course. }{ }^{f, g}\end{array}$ & $2.8(1.61)$ & $2.3(1.23)$ & 4.50 & $<.001$ \\
\hline & $\begin{array}{l}\text { I felt there was a match between the con- } \\
\text { tent in the textbook and the specific } \\
\text { learning objectives for this course. }\end{array}$ & $2.6(1.32)$ & $2.3(1.16)$ & 2.62 & .009 \\
\hline \multirow[t]{2}{*}{ Engagement } & $\begin{array}{l}\text { The information in the textbook has helped } \\
\text { me to maintain my interest in the class. }\end{array}$ & $3.1(1.57)$ & $2.6(1.31)$ & 4.23 & $<.001$ \\
\hline & $\begin{array}{l}\text { I felt the information in the textbook chal- } \\
\text { lenged my thinking in a positive way. }\end{array}$ & $3.1(1.50)$ & $2.6(1.20)$ & 4.81 & $<.001$ \\
\hline
\end{tabular}

OER indicates open educational resource.

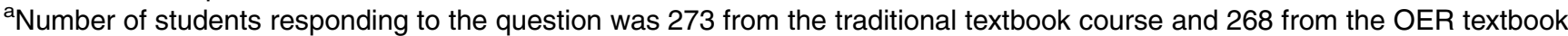
course; ${ }^{\mathrm{b}}$ Response values were (1) Daily, (2) 2-3 times a week, (3) 2-3 times a month, (4) 2-3 times for the semester, (5) Never; ' Response values were (1) I read the textbook fairly closely, (2) I mostly used the textbook to supplement the course information but not as a main source of information, (3) I mostly referred to the visual material like images, charts, graphs, and tables, (4) I didn't use the textbook very much for the course, (5) Other; ${ }^{d}$ Response values were (1) I read all of almost all of the textbook, (2) I read much of the textbook, (3) I read about half of the textbook, (4) I read a little bit of the textbook, (5) I read none or almost none of the textbook; ${ }^{e}$ Number of students responding to the question was 276 from the traditional textbook course and 269 from the OER textbook course, and response values were (1) Excellent, (2) Above average, (3) Average, (4) Below average, (5) Poor; ${ }^{\dagger}$ Response values were (1) Strongly Agree, (2) Agree, (3) Somewhat agree, (4) Neither agree nor disagree, (5) Somewhat disagree, (6) Disagree, (7) Strongly Disagree; 9Number of students responding to the question was 277 from the traditional textbook course and 271 from the OER textbook course; ${ }^{\mathrm{h}}$ Number of students responding to the question was 277 from the traditional textbook course and 269 from the OER textbook course; 'Number of students responding to the question was 279 from the traditional textbook course and 272 from the OER textbook course. 
Table 4. Student Open-Ended Verbatim Responses to the Question "What are the features, if any, that you liked about the textbook for this class?" Organized by Themes

\begin{tabular}{|c|c|c|c|}
\hline Theme & Subtheme & $\begin{array}{l}\text { Traditional Textbook } \\
\text { Exemplifying Quotation(s) and } \\
\text { Frequency of Responses } \\
\text { Matching the Theme }\end{array}$ & $\begin{array}{l}\text { OER Textbook } \\
\text { Exemplifying Quotation(s) and } \\
\text { Frequency of Responses } \\
\text { Matching the Theme }\end{array}$ \\
\hline \multirow[t]{4}{*}{ Structure } & $\begin{array}{l}\text { Format and } \\
\text { organization }\end{array}$ & $\begin{array}{l}\mathrm{n}=20 \\
\text { I liked being able to find any of the } \\
\text { topics in the table of contents. } \\
\text { I liked how the chapters were split } \\
\text { up and evenly distributed with } \\
\text { what we were taught in class that } \\
\text { day. }\end{array}$ & $\begin{array}{l}\mathrm{n}=22 \\
\text { I liked the organization of the text- } \\
\text { book so it was easy to follow. } \\
\text { They kept each topic on one page } \\
\text { and would make the page longer, } \\
\text { if necessary. I liked that I didn't } \\
\text { have to flip back and forth } \\
\text { between pages because the sec- } \\
\text { tions were split up. }\end{array}$ \\
\hline & Visual enhancement & $\begin{array}{l}\mathrm{n}=61 \\
\text { I liked the detailed charts and } \\
\text { graphs, which were easy ways of } \\
\text { seeing nutritional information in an } \\
\text { organized way. } \\
\text { I liked how it showed me diagrams } \\
\text { and step-by-step models. }\end{array}$ & $\begin{array}{l}\mathrm{n}=13 \\
\text { I'm a visual learner and if there } \\
\text { aren't much drawing or pictures } \\
\text { showing exactly what their } \\
\text { explaining in the book, I'll lose my } \\
\text { concentration and comprehension } \\
\text { of what I was just reading, how- } \\
\text { ever, this book provided a lot of } \\
\text { pictures throughout the chapter } \\
\text { showing and demonstrating what } \\
\text { they were explaining and going } \\
\text { over. It helped learning the con- } \\
\text { cepts much easier. } \\
\text { I also liked how there were many } \\
\text { pictures and graphs that helped to } \\
\text { further expand on the written text. }\end{array}$ \\
\hline & $\begin{array}{l}\text { Navigation and } \\
\text { search }\end{array}$ & $\begin{array}{l}\mathrm{n}=6 \\
\text { Easy to navigate to the pages you } \\
\text { need to be at. } \\
\text { Sections were easy to find. }\end{array}$ & $\begin{array}{l}n=33 \\
\text {.. time saving having the option to } \\
\text { search through the book electroni- } \\
\text { cally. } \\
\text { The dropdown menu featuring the } \\
\text { specific sections proved very use- } \\
\text { ful to accessing the very informa- } \\
\text { tion that I need. }\end{array}$ \\
\hline & Detailed & $\begin{array}{l}\mathrm{n}=26 \\
\text { Reading the textbook before the } \\
\text { lectures helped me to gain a } \\
\text { deeper and more in-depth under- } \\
\text { standing. } \\
\text { A more in-depth analysis on the } \\
\text { things we learned in the class. }\end{array}$ & $\begin{array}{l}\mathrm{n}=12 \\
\text { Provided more detailed information } \\
\text { and gave me a better understand- } \\
\text { ing of the course. } \\
\text { Detailed and well-written informa- } \\
\text { tion that was easy to follow. }\end{array}$ \\
\hline Access & $\begin{array}{l}\text { Convenience and } \\
\text { accessibility }\end{array}$ & $\begin{array}{l}\mathrm{n}=13 \\
\text { I like that their is access to an online } \\
\text { version of the textbook so that I } \\
\text { don't have to carry the textbook } \\
\text { with me. } \\
\text { As mentioned, since the textbook is } \\
\text { not bound, I can take out the sec- } \\
\text { tions that is being covered and } \\
\text { place them in a binder to either } \\
\text { study or take to class rather than } \\
\text { carrying the entire textbook } \\
\text { around for the entire semester. }\end{array}$ & $\begin{array}{l}\mathrm{n}=74 \\
\text { I really liked how the textbook for } \\
\text { this class was easy to use and it } \\
\text { was easy to access... Overall, the } \\
\text { online book is a very effective and } \\
\text { efficient way of learning the sub- } \\
\text { jects in the class. } \\
\text { But it was also really convenient not } \\
\text { to have to carry around a heavy } \\
\text { textbook, plus I had access to that } \\
\text { resource any time I had internet } \\
\text { and a smart device. }\end{array}$ \\
\hline
\end{tabular}




\begin{tabular}{|c|c|c|c|}
\hline \multirow[t]{2}{*}{ Theme } & Subtheme & $\begin{array}{l}\text { Traditional Textbook } \\
\text { Exemplifying Quotation(s) and } \\
\text { Frequency of Responses } \\
\text { Matching the Theme }\end{array}$ & $\begin{array}{l}\text { OER Textbook } \\
\text { Exemplifying Quotation(s) and } \\
\text { Frequency of Responses } \\
\text { Matching the Theme }\end{array}$ \\
\hline & Cost & $\begin{array}{l}\mathrm{n}=1 \\
\text { I did enjoy how this textbook was } \\
\text { not to overpriced like for classes } \\
\text { such as chem or bio where the } \\
\text { textbooks cost about } \$ 200+\text { with } \\
\text { an online system used for } \\
\text { homework. }\end{array}$ & $\begin{array}{l}\mathrm{n}=48 \\
\text { I'm a huge supporter of the move- } \\
\text { ment in the UH system to adopt } \\
\text { open resources for school. The } \\
\text { cost-free aspect appeals the } \\
\text { most. } \\
\text { Free cost that is really helpful and } \\
\text { appreciative. }\end{array}$ \\
\hline \multirow[t]{3}{*}{ Application } & $\begin{array}{l}\text { Real-world/place- } \\
\text { based application }\end{array}$ & $\begin{array}{l}\mathrm{n}=14 \\
\text { I liked how it included everyday life } \\
\text { things like Starbucks, or McDo- } \\
\text { nalds. Something that was on a } \\
\text { relatable issue. } \\
\text { Real-world examples and exercises } \\
\text { are included following sections. }\end{array}$ & $\begin{array}{l}\mathrm{n}=15 \\
\text { I like how it uses examples of the } \\
\text { foods we usually eat here in } \\
\text { Hawaii. } \\
\text { The info read for this course helped } \\
\text { me to apply it in real life. } \\
\text { The incorporation of the Hawaiian } \\
\text { culture is also unique to our uni- } \\
\text { versity and I appreciate it. }\end{array}$ \\
\hline & Future reference & $\begin{array}{l}\mathrm{n}=3 \\
\text { I will definitely be using this book in } \\
\text { my future endeavors. }\end{array}$ & $\begin{array}{l}\text { No responses related to this } \\
\text { subtheme }\end{array}$ \\
\hline & $\begin{array}{l}\text { Relation to course } \\
\text { content }\end{array}$ & $\begin{array}{l}\mathrm{n}=33 \\
\text { There were questions for us at the } \\
\text { end of the chapters so we could } \\
\text { test our understanding. I liked the } \\
\text { relevance to the course objec- } \\
\text { tives. } \\
\text { I like how it directly corresponds to } \\
\text { what is taught in class. }\end{array}$ & $\begin{array}{l}\mathrm{n}=6 \\
\text { I like the book gives good informa- } \\
\text { tion to help me on my homework. } \\
\text { It was very easy and informational } \\
\text { for quizzes and exams. } \\
\text { Correlation with course. }\end{array}$ \\
\hline All & & $\begin{array}{l}\mathrm{n}=2 \\
\text { Everything. }\end{array}$ & $\begin{array}{l}\mathrm{n}=2 . \\
\text { Liked it all. }\end{array}$ \\
\hline Did not like/use & & $\begin{array}{l}\mathrm{n}=20 \\
\text { Did not like that we had to obtain a } \\
\text { copy when not needed. } \\
\text { I honestly think there are probably } \\
\text { better textbooks out there. }\end{array}$ & $\begin{array}{l}\mathrm{n}=10 \\
\text { Didn't use the textbook. } \\
\text { Nothing }\end{array}$ \\
\hline
\end{tabular}

OER indicates open educational resource. 
Table 5. Student Open-Ended Verbatim Responses to the Question "What are the features, if any, that you disliked about the textbook for this class?" Organized by Themes

\begin{tabular}{|c|c|c|c|}
\hline Theme & Subtheme & $\begin{array}{c}\text { Traditional Textbook } \\
\text { Exemplifying Quotation(s) and } \\
\text { Frequency of Responses Matching } \\
\text { the Theme }\end{array}$ & $\begin{array}{l}\text { OER Textbook } \\
\text { Exemplifying Quotation(s) and } \\
\text { Frequency of Responses } \\
\text { Matching the Theme }\end{array}$ \\
\hline \multirow[t]{3}{*}{ Structure } & $\begin{array}{l}\text { Formatting and } \\
\text { organization }\end{array}$ & $\begin{array}{l}\mathrm{n}=10 \\
\text { There were } 2 \text { different sets of page } \\
\text { numbers for the same pages, which } \\
\text { was soooooo confusing. That needs } \\
\text { to be reconfigured. } \\
\text { The information was all over the place. } \\
\text { I didn't like how everything was } \\
\text { bunched together. }\end{array}$ & $\begin{array}{l}\mathrm{n}=13 \\
\text { I was a bit confused with the organi- } \\
\text { zation } \\
\text { The lesson number didn't corre- } \\
\text { spond with the chapter numbers in } \\
\text { the book, so it made it a little diffi- } \\
\text { cult to find information. } \\
\text { There were no page numbers. } \\
\text { Pages should be numbered. }\end{array}$ \\
\hline & $\begin{array}{l}\text { Navigation and } \\
\text { search }\end{array}$ & $\begin{array}{l}\mathrm{n}=1 \\
\text { Difficulty finding key terms. }\end{array}$ & $\begin{array}{l}\mathrm{n}=17 \\
\text { Scrolling/getting to the next page } \\
\text { was somewhat difficult. } \\
\text { Online format can be somewhat } \\
\text { hard to navigate. } \\
\text { I wish that there was a scrolling } \\
\text { option rather than just click to turn } \\
\text { the page. }\end{array}$ \\
\hline & Visuals inadequate & $\begin{array}{l}\mathrm{n}=4 \\
\text { It didn't have enough pictures. } \\
\text { Not enough examples of the terms } \\
\text { given to us. }\end{array}$ & $\begin{array}{l}\mathrm{n}=1 \\
\text { Lack of graphics and tables. }\end{array}$ \\
\hline \multirow[t]{2}{*}{ Access } & Cost & $\begin{array}{l}\mathrm{n}=14 \\
\text { Textbooks are expensive. } \\
\text { It was expensive, I can't return it or sell } \\
\text { it back. } \\
\text { Too costly when I have to buy other } \\
\text { books for core classes. }\end{array}$ & $\begin{array}{l}\text { No responses related to this } \\
\text { subtheme }\end{array}$ \\
\hline & $\begin{array}{l}\text { Textbook copy } \\
\text { options }\end{array}$ & $\begin{array}{l}\mathrm{n}=27 \\
\text { I disliked how it was a bunch of papers } \\
\text { and you had to get a binder to hold } \\
\text { them. } \\
\text { Pages are thin so need to be careful } \\
\text { when turning or they will tear. }\end{array}$ & $\begin{array}{l}\mathrm{n}=19 \\
\text { I would like a cheap option for a } \\
\text { paper book. I like having a book to } \\
\text { read but that's just personal pref- } \\
\text { erence. Anytime you can save } \\
\text { money though it's a plus so I } \\
\text { didn't mind. } \\
\text { That it had to be an online resource, } \\
\text { I think it would have been easier to } \\
\text { have a hard copy that I could } \\
\text { highlight and take notes on. }\end{array}$ \\
\hline Did not... & Need & $\begin{array}{l}\mathrm{n}=25 \\
\text { I feel like I didn't need the book to } \\
\text { complete this course. } \\
\text { I felt the textbook almost wasn't } \\
\text { needed for the course because the } \\
\text { lectures were so helpful in my under- } \\
\text { standing of the course materials. }\end{array}$ & $\begin{array}{l}\mathrm{n}=6 \\
\text { I barely used it because a lot of the } \\
\text { quizzes are guided by the Power- } \\
\text { Points. } \\
\text { I didn't need it to succeed. }\end{array}$ \\
\hline & Buy & $\begin{array}{l}n=3 \\
\text { I didn't buy the textbook because all } \\
\text { the information can be research on } \\
\text { the Internet for free. We have access } \\
\text { to almost the same information for } \\
\text { free so I don't see the need to buy the } \\
\text { textbook. }\end{array}$ & $\begin{array}{l}\text { No responses related to this } \\
\text { subtheme }\end{array}$ \\
\hline
\end{tabular}




\section{Table 5. (Continued)}

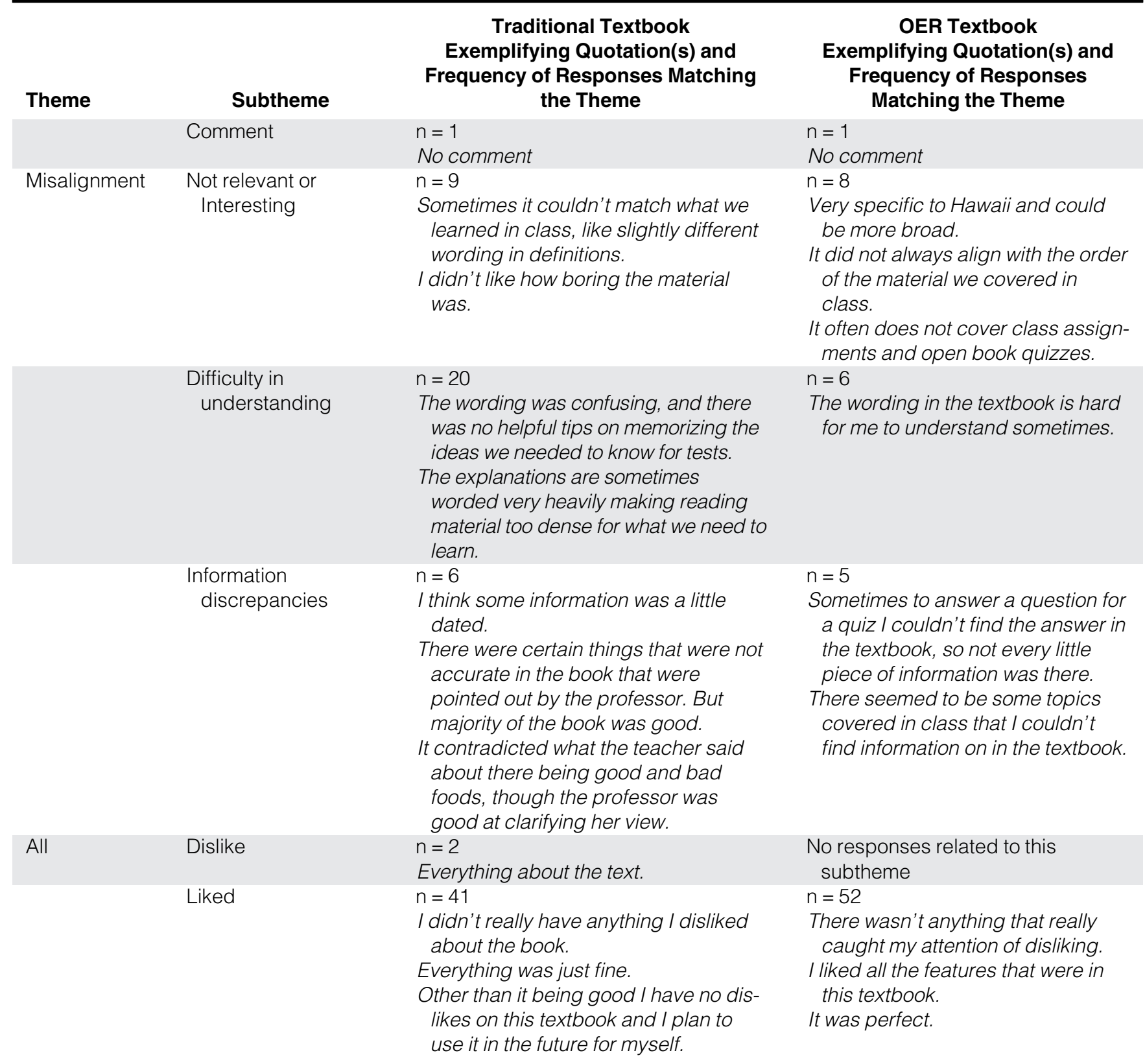

OER indicates open educational resource.

instructor differences by ensuring the mode of instruction did not differ by instructor each semester. Students in the online course may have had a more favorable interaction with the OER textbook, as it was more easily integrated into the online course's Web site, which was not used for the face-to-face section. However, another study found that there were no differences in usage, engagement, and perception between online and face-to-face courses that used an OER textbook or a traditional textbook. ${ }^{21}$ Furthermore, this study only examined the students' usage, engagement, and perception and did not examine what instructors thought about using the OER textbook in their courses. However, a previous study done by Delimont ${ }^{20}$ found that instructors also have a positive perception of teaching with an OER textbook. The generalizability of the sample to the contiguous US may also be a potential limitation.

\section{IMPLICATIONS FOR RESEARCH AND PRACTICE}

Introductory nutrition is a common course across postsecondary institutions. As more institutions adapt OER textbooks to reduce costs for students and increase instructor control of content, it is important to demonstrate that these resources do not hinder academic performance and are positively received by students. Instructors wishing to adapt an OER introductory 
textbook to their course may be more likely to find that students' usage, engagement, and perception will be improved and that their students' mastery of the material will not be hindered. OER textbooks seem to be an appropriate economical substitution for a traditional textbook. However, it is important to note that an institution may need a significant amount of time and resources to develop and/or adapt to an OER textbook. The OER textbook used in this study took over a year to create, as the authors for the textbook desired a textbook that reflected their location, and there was no OER introductory textbook in existence at that time that achieved this goal.

\section{ACKNOWLEDGMENT}

The authors wish to thank the students and instructors who participated in this research. In addition, the financial support provided by the Children's Healthy Living Summer Institute and the University of Hawai'i Outreach College is also acknowledged.

\section{SUPPLEMENTARY DATA}

Supplementary data related to this article can be found at https://doi. org/10.1016/j.jneb.2019.08.006.

\section{REFERENCES}

1. Baum S, Ma J, Payea K. Trends in public higher education: enrollment, prices, student aid, revenues, and expenditures. New York, NY: College Board Advocacy \& Policy Center; 2012. https:// trends.collegeboard.org/sites/default/ files/trends-2012-public-higher-education-expenditures-brief.pdf. Accessed February 1, 2019.

2. Bureau of Labor and Statistics. College tuition and fees increases 63 percent since January 2006. 2016. https:// www.bls.gov/opub/ted/2016/collegetuition-and-fees-increase-63-percent- since-january-2006.htm. Accessed March 1, 2019.

3. Senack E. Fixing the Broken Textbook Market: How Students Respond to High Textbook Costs and Demand Alternatives. Washington, DC: US Public Interest Research Group; 2014. https://washpirg. $\mathrm{org} / \mathrm{sites} / \mathrm{pirg} /$ files/reports/1.27.14\% 20Fixing\%20Broken\%20Textbooks\% 20Report.pdf. Accessed March 3, 2019 .

4. Wiley D, Green C. Why openness in education? In: Oblinger DG, ed. Game Changers: Education and Information Technologies. Washington, DC: Educase; 2012.

5. Lindshield BL, Adhikari K. Online and campus college students like using an open educational resource instead of a traditional textbook. J Online Learn Teach. 2013;9:26-37.

6. Feldstein A, Martin M, Hudson A, Warren K, Hilton J III, Wiley D. Open textbooks and increased student access and outcomes. Eur J Open Distance E-Learn. 2012;2:1-9.

7. Fischer L, Hilton J III, Robinson TJ, Wiley DA. A multi-institutional study of the impact of open textbook adoption on the learning outcomes of postsecondary students. J Comput High Educ. 2015;27:159-172.

8. Cohen NL, Carbone ET, BeffaNegrini PA. The design, implementation, and evaluation of online credit nutrition courses: a systematic review. J Nutr Educ Behav. 2011;43:76-86.

9. Benton-King C, Webb DF, Holmes Z. A distance education in undergraduate dietetic education. J Allied Health. 2005;34:36-39.

10. Open Education Group. The COUP framework. http://openedgroup.org/ coup. Accessed March 3, 2019.

11. Banna J, Grace Lin MF, Stewart M, Fialkowski MK. Interaction matters: strategies to promote engaged learning in an online introductory nutrition course. $J$ Online Learn Teach. 2015;11:249-261.

12. Trowler V, Trowler P. Student engagement evidence summary. York, UK: The Higher Education Academy; 2010. https://eprints.lancs.ac.uk/61680/1/ Deliverable_2._Evidence_Summary.
_Nov_2010.pdf. Accessed August 8, 2019.

13. Smith GA. Place-based education: learning to be where we are. Phi Delta Kappan. 2002;83:584-594.

14. Bliss TJ, Robinson TJ, Hilton J, Wiley DA. An OER COUP: college teacher and student perceptions of open educational resources. J Interact Media Educ. 2013;(1):4.

15. Hilton JL III, Fischer L, Wiley D, William L. Maintaining momentum toward graduation: OER and the course throughput rate. Int Rev Res Open Distrib Learn. 2016;17:18-27.

16. Fade SA, Swift JA. Qualitative research in nutrition and dietetics: data analysis issues. J Hum Nutr Diet. 2011;24:106114.

17. McHugh ML. Interrater reliability: the kappa statistic. Biochem Med (Zagreb). 2012;22:276-282.

18. Allen G, Guzman-Alvarez A, Smith A, Gamage A, Molinaro M, Larsen DS. Evaluating the effectiveness of the open-access ChemWiki resource as a replacement for traditional general chemistry textbooks. Chem Educ Res Pract. 2015;16:939-948.

19. Hilton J III. Open educational resources and college textbook choices: a review of research on efficacy and perceptions. Educ Technol Res Dev. 2016; 64:573-590.

20. Delimont N, Turtle EC, Bennett A, Adhikari K, Lindshield BL. University students and faculty have positive perceptions of open/alternative resources and their utilization in a textbook replacement initiative. Res Learn Technol. 2016;24:29920.

21. Cuttler C. Students' use and perceptions of the relevance and quality of open textbooks compared to traditional textbooks in online and traditional classroom environments. Psychol Learn Teach. 2018;18:65-83.

22. Cooney C. What impacts do OER have on students? Students share their experiences with a health psychology OER at New York City College of Technology. Int Rev Res Open Distrib Learn. 2017;18:3111. 